Studia Anglica Posnaniensia 49/4, 2014

doi: 10.1515/stap-2015-0011

\title{
NURSLINGS OF PROTESTANTISM: THE QUESTIONABLE PRIVILEGE OF FREEDOM IN CHARLOTTE BRONTË'S VILLETTE
}

\author{
MONIKA MAZUREK
}

Pedagogical University of Cracow

\begin{abstract}
In Charlotte Brontë's Villette, a number of foreigners at various points express their amazement or admiration of the behaviour of Englishwomen, who, like the novel's narrator Lucy Snowe, travel alone, visit public places unchaperoned and seem on the whole to lead much less constrained lives than their Continental counterparts. This notion was apparently quite widespread at this time, as the readings of various Victorian texts confirm - they often refer to the independence Englishwomen enjoyed, sometimes with a note of caution but often in a self-congratulatory manner. Villette, the novel which, similarly to its predecessor, The Professor, features a Protestant protagonist living in a Catholic country, makes a connection between Lucy's Protestantism and her freedom, considered traditionally in English political discourse to be an essentially English and Protestant virtue. However, as the novel shows, in the case of women the notion of freedom is a complicated issue. While the pupils at Mme Beck's pensionnat have to be kept in check by a sophisticated system of surveillance, whose main purpose is to keep them away from men and sex, Lucy can be trusted to behave according to the Victorian code of conduct, but only because her Protestant upbringing inculcated in her the need to control her desires. The Catholics have the Church to play the role of the disciplinarian for them, while Lucy has to grapple with and stifle her own emotions with her own hands, even when the repression is clearly the cause of her psychosomatic illness. In the end, the expectations regarding the behaviour of women in England and Labassecour are not that much different; the difference is that while young Labassecourians are controlled by the combined systems of family, school and the Church, young Englishwomen are expected to exercise a similar control on their own.
\end{abstract}

Keywords: Charlotte Brontë, Villette, Catholicism, Protestantism, freedom of women

In February 1842 Charlotte Brontë, together with her sister Emily, set out on what was going to be their first and only foreign journey. They were going to Brussels to become students, and later on students-cum-teachers at the Pensionnat Héger. 
The purpose of their stay in the Belgian school was to brush up on their qualifications in preparation for setting up their own school for girls. While the plan came to nothing, the sojourn in Brussels proved to be formative for Charlotte. Her tutor and owner of the school, the irascible, plain and fascinating Constantin Héger, shaped her writing style, mercilessly cutting down on her tendencies for digressions and purple prose; he also provided a sentimental education, since she fell unhappily in love with him and the heroes modelled on him were going to haunt much of her later writings. Finally, and most relevantly for this article, two years in Belgium provided her with the material for her début novel, The Professor (1857) which, though unpublished in her lifetime, mutated over time into what was going to be Charlotte Brontë's last novel, Villette (1853).

The reason why Belgium turned out to be the making of Charlotte Brontë as a writer is not only the quasi-creative writing course she went through there under the tutelage of M. Héger. Her first trip abroad was an encounter with the Other, not only in terms of nationality and language but also religion. At the time of Brontë's leaving for Belgium, Roman Catholics in England were a small minority, of which she had little first-hand knowledge, if any at all. While the number of Catholics living in England had been growing rapidly in the period after the Catholic Emancipation of 1829, mostly owing to immigration from Ireland, it still did not amount to much more than 5 per cent of the general population of England and Wales (Wheeler 2006: 25). In Belgium Brontë found herself surrounded by what back home was a minority denomination (although traditionally much feared and distrusted), here a dominating religion which cast her in the role of the excluded one, the Other, the heretic. This confrontation with the culture which was similar to her own and at the same time its reverse could be compared to Alice's journey through the looking-glass a few decades later; while her stay in Belgium was for her personally unsettling and difficult, it could be seen as a necessary step in her development as a writer.

One of the aspects in which Continental culture was apparently so different from the English one, was its approach to the control that should be exercised by families and guardians over women, especially young and unmarried ones. In Villette, a number of foreigners at various points express their amazement or admiration at the behaviour of Englishwomen, who, like the novel's narrator Lucy Snowe, travel alone, visit public places unchaperoned and seem on the whole to lead much less constrained lives than their Continental counterparts. M. Paul, Lucy's fellow teacher says, catching Lucy in a museum viewing what he deems to be an inappropriate painting for an unmarried young woman to look at: "You nurslings of Protestantism astonish me. You unguarded Englishwomen walk calmly amidst red-hot ploughshares and escape burning. I believe, if some of you were thrown into Nebuchadnezzar's hottest furnace you would 
issue forth untraversed by the smell of fire" (Villette, 274). ${ }^{1}$ The freedom enjoyed by English young women in comparison with their Continental sisters might be grossly exaggerated in comparison with the reality of the lives of Victorian women; the stereotype, however, did recur in various Victorian texts with its distant echoes carried as far forward as Henry James's Daisy Miller (1878) (here transposed upon an American girl) and The Awkward Age (1899), with Nanda and Aggie, two young girls representing respectively the permissive English and the restrictive Continental mode of upbringing.

The purpose of the present article is to examine the idea of the much-vaunted freedom of English women, using Villette as a sort of case study. Villette, I believe, may turn out to be a useful example because it emphasizes the role of Protestant ethics in explaining the liberty enjoyed by English women. In the Victorian discourse on women one could discern a note of British exceptionalism; British women, the argument went, could be trusted to move and act independently because the good Protestant education they had received inculcated in them all the right principles of virtue and self-control. As all Protestants, they were taught to rely on their own conscience and direct contact with God, instead of blindly obeying the dictates of priests; thus in testing situations they behaved in the morally right way, even if the punishing eye of a parent, guardian or priest was not upon them. However, Villette also subtly undermines this belief, showing through its protagonist, Lucy Snowe, that this self-control came at a price, bringing with it a variety of psychosomatic symptoms. Both religions are systems of social power, and both are similarly restrictive when it comes to the norms for female behaviour (Clark-Beattie 1986: 829-830); the superiority of Protestant over Catholic education boils down to the fact that in Catholic schools norms are imposed externally, while in Protestant education women are expected to "internalize the destructive strictures of patriarchy” (Gilbert and Gubar 1979: 400).

The vital role played by Protestantism in the development of the character of Englishwomen is repeatedly emphasized in Villette, as the above quote about "nurslings of Protestantism" showed. Similarly, when Lucy meets for the first time Ginevra Fanshawe, her future acquaintance at Mme Beck's pensionnat, travelling alone on a packet boat to the Continent, she makes the following observation:

Foreigners say that it is only English girls who can thus be trusted to travel alone, and deep is their wonder at the daring confidence of English parents and guardians. As for the "jeunes Meess", by some their intrepidity is pronounced masculine and "inconvenant", others regard them as the passive victims of an educational and theological system which wantonly dispenses with proper "surveillance".

(Villette, 117)

1 All references to Charlotte Brontë's Villette are from Kate Lawson’s edition for Broadview Press. 
The key to understanding the theological system that apparently made English girls so shockingly liberated in comparison with Continental ones, who were kept under close watch, lies not so much in the Thirty-Nine Articles or the writings of Anglican theologians, but in their political implications. Indeed, the discourse on personal freedom in Villette is indebted to a large degree to the traditional English arguments which perceived liberty to be the defining feature of Protestantism, as for instance George Henry Lewes did in an editorial for The Leader published in 1850, which was read and praised by Brontë (Clark-Beattie 1986: 823). Almost since the beginnings of the Reformation in England, Protestant writers (most notably Milton, Marvell and Locke) argued that personal and political liberty, perceived as a traditionally English virtue, would be impossible without Protestantism, which granted the right of private judgement to every believer and limited the authority of the Church, making it subordinate to the teachings of the Scripture and the rule of civil magistrates (Fatovic 2005: 45-48). The fact that the most powerful Catholic countries and England's rivals, such as France and Spain, were absolutist monarchies, served to strengthen the link between Protestantism and freedom even more (Fatovic 2005: 45).

The Protestant emphasis on the role of faith and grace, which could not be earned by any amount of purchased indulgences or recited prayers, in connection with the redefined role of the Church, meant that every believer was personally responsible for his or her own salvation. ${ }^{2}$ The reduced number of sacraments and dispensing with the auricular confession altogether changed the balance of power between the clergy and the individual members of a congregation, with the former demoted from their role of intermediaries between God and men to that of assistants or ministers. In contrast, Catholics, as it were, delegated the whole matter of their spiritual welfare into the hands of the professionals. As Protestant polemicists never tired of pointing out, Catho-

2 The key sources for my discussion on Protestantism and its attitudes to Catholicism, especially in the Victorian age are, apart from those listed in the bibliography: Linda Colley. 1992. Protestants. In Britons: Forging the nation 1707-1837, 11-54. New Haven and London: Yale University Press; Susan M. Griffin. 2004. Anti-Catholicism and nineteenthcentury fiction. Cambridge: Cambridge University Press; Maureen Moran. 2007. Catholic sensationalism and Victorian literature. Liverpool: Liverpool University Press; Patrick R. O’Malley. 2006. Catholicism, sexual deviance and Victorian Gothic culture. Cambridge: Cambridge University Press; Michael E. Schiefelbein. 2001. The lure of Babylon. Seven Protestant novelists and Britain's Catholic revival. Macon: Mercer University Press; Raymond Tumbleson. 1998. English Protestant imagination: Nationalism, religion and literature, 1660-1745. Cambridge: Cambridge University Press; John Wolffe. 1991. The Protestant crusade in Great Britain 1829-1860. Oxford: Clarendon Press; Robert J. Klaus. 1987. The Pope, the Protestants and the Irish. New York: Garland; Frank H. Wallis. 1993. Popular Anti-Catholicism in mid-Victorian Britain. Lampeter: E. Mellen Press. 
lics were nothing better than marionettes whose strings were pulled by their father confessors, with their consciences wholly externalized and all their ethical dilemmas solved by the decrees of the Church or its representatives. The story of the poisoning of King John by a treacherous monk from Swinestead Abbey, as recorded by Foxe in Acts and Monuments (1570), is the epitome of what Protestants perceived as Catholics ceding responsibility for their own deeds into the hands of the Church: the monk receives absolution from his abbot in advance for the murder he is about to commit and after his death he "had continuallye from thenceforth three Monkes to sing Masses for hys soule, confirmed by their generall chapter" (Foxe 1570: 344). The point of Foxe's story, driven further home by the famous woodcuts, was impossible to miss: Catholics believed they could literally get away with murder, provided it was the murder sanctioned by their Church. For Catholics the right thing to do was what their Church considered to be right, even if it meant a travesty of God's and nature's laws. Catholicism presented in this way served as the foil to virtuous Protestantism, where abiding by a code of conduct did not depend on the external authority of the Church commanding the believers what to do, but on the highly internalized system of ethics, fortified by prayer and reading of the Scripture, through which an individual Christian achieved the unmediated experience of God. Therefore, it followed that Protestants earned their freedom of conscience through its constant exercise, while Catholics left their consciences in the care of priests.

This long tradition of associating freedom with Protestantism contributed to the way the words "freedom" and "liberty" were used in the mid- $19^{\text {th }}$ century, when Villette was written. The religious freedom, allowing all English people to interpret the Bible for themselves shaped their political culture; the British state, relatively laissez-faire in comparison with the Continental absolutist monarchies, did not succumb to the wave of revolution in 1848 because of the British instinctive self-discipline (Parry 2006: 78). Thus, "freedom" in British discourse of that period did not mean merely the freedom of every Englishman to do "as he likes", as Matthew Arnold put it ironically nearly two decades later in Culture and Anarchy (1993 [1869]: 64). On the contrary,

\footnotetext{
... most Liberal Anglicans and Nonconformists would have accepted that the truest definition of liberty was reconciliation with God. Man was made to move with perfect freedom in harmony with the divine order, but his sinfulness had deprived him of that freedom by obscuring the knowledge of God that would give it to him. The idea of attaining freedom from the bondage of sin is part of the very first definition of the word liberty in the Oxford English Dictionary.
}

(Parry 2006: 92-93) 
When Brontë's contemporaries spoke or wrote about freedom, they thought not about a primeval state of anarchy, but this ideal state of being purged from freedom-limiting sin. As Protestants, they had a better chance of coming close to the ideal than Catholics, whose moral vision was interfered with by priestcraft. Owing to that, British society could be largely self-governing while the security of Catholic countries and the civic behaviour of their inhabitants depended on the surveillance and control of the state and Church; when these systems failed, the countries slid into revolutionary chaos.

From the point of view of Protestant writers the right of Englishmen to enjoy their freedom was unquestionable; the right of Englishwomen, however, was more problematic. Women as the weaker sex, not only physically but also morally, were naturally subject to the authority of the male members of their families. Much of the moral panic inspired by Catholicism was due to the fact that Catholic women, by submitting themselves to the authority of priests, exchanged the natural authority of their husbands or fathers for that of fake "spiritual fathers", undermining the God-ordained structure of family. It became also commonplace in Protestant writings of the nineteenth century to claim that most of the converts to Catholicism were women and "unmanly" men because of its relying on emotions, liturgy appealing to the senses and the comforting fictions such as the intercession of the gentle Mother Mary and purgatory, giving sinners a second chance at achieving salvation (Engelhardt 2000: 47); Dr Johnson alluded to this supposed propensity of women towards Catholicism as a more lenient religion when he said "I wonder that women are not all Papists" (Boswell 1998: 1289).

However, many Victorian writers, especially female Evangelicals, used the genre of the religious novel in order to portray model Protestant heroines, bravely defending their faith against their Popish persecutors. Such heroines could appear in the historical novel, or its sub-genre, which could be termed after Miriam Burstein "the Reformation tale" (Burstein 2005: 74), the novel dealing with the early phases of the Reformation, or with the proto-Reformation movements, Wycliffe and the Lollards being one of the favourite subjects. The purpose of these novels, usually stated more or less explicitly in the preface or in the authorial asides, was to awaken too-complacent Protestant readers to the dangers of Roman Catholicism, encroaching on British soil and threatening to achieve in the nineteenth century through insidious propaganda what it failed to achieve in the sixteenth century through brute force (Burstein 2005: 76). The female protagonists of such novels, either fictitious, like Beatrice in Chillon (1845) by Jane Willyams or historical (mostly borrowed from Foxe), such as Alice Benden, featuring both in Alice Benden, or the Bowed Shilling (1838) by Charlotte Elizabeth Tonna and All's Well (1893) by Emily Sarah Holt, set the example of personal courage, piety and unswerving adherence to Protestantism 
which amazed even their Catholic oppressors. The heroines of the novels set in contemporary Britain, such as Beatrice (1852) by Catherine Sinclair, are similar paragons of virtue, who, although they do not have to cope with the Inquisition, are equally brave and staunch defenders of Protestantism against the dangerous machinations of gliding Jesuits and especially Jesuitesses.

As can be seen, although on the one hand Protestant writers, in keeping with the vast majority of all European writers, widely assumed that women were innately weak physically and morally, on the other hand they perceived their countrywomen as somewhat excepted from this general rule. Protestant women (meaning automatically most of English women) were seen as superior and more virtuous than their Catholic sisters, thanks to the tenets of their upbringing, which emphasized personal responsibility for one's salvation. Since their conscience received such training, they could be trusted to behave appropriately out of their own accord and not because they were under the surveillance of their guardians; hence they could be granted more freedom. The accounts of the great liberty that English women enjoyed may have been exaggerated if we compare them to other texts; Charlotte Mary Yonge's Heartsease (1854) provides us with an example illustrating the limitations faced by young Victorian ladies in everyday life. In the story a self-sacrificing pregnant young woman forces herself to go to a ball despite feeling unwell rather than to allow her husband's unmarried sister (who is actually her senior) to attend the occasion unchaperoned. Nevertheless, the independence of English women was a recurring self-congratulatory motif in Victorian writings, even if the commendations were sometimes qualified, as in this example from Fraser's Magazine:

[French women] admire the courage when speaking to English ladies; what name
they give to it when speaking of them we need not inquire. We may congratulate
our countrywomen on their self-dependence, and on being born in times when the
tone of opinion and habit make such freedom possible. We could perhaps wish
that some few who have made a boast of their independence in various parts of
Europe had kept it for use and not for show, - we may think that the adventures of
some unprotected females were hardly such as to be proud of, and some others not
worth recording, - and we may perhaps regret that some who made 'a timely re-
treat' should ever have made so rash an advance; but on the whole we may well
rejoice to see such numbers use a rational freedom.

(Anonymous 1861: 352)

The reviewer was probably referring to two popular travel books by Emily Lowe, Unprotected Females in Norway (1857) and Unprotected Females in Sicily, Calabria, and on the Top of Mount Aetna (1859). The mocking titles alluded clearly to what was by the time of publishing these books an established cultural cliché. Indeed, Google Ngram Viewer (pace all its problems) indicates that the phrase appeared around 1847 and enjoyed its greatest popularity until 
1865. This curious expression, reminiscent of today's "unaccompanied minor", reflects complex Victorian attitudes to women's independence, of which women travelling without the company of a male family member were the epitome. ${ }^{3}$ The phrase seems to have gained popularity with a series of humorous scenes published in Punch between 1849-1850, titled "Scenes from the Life of an Unprotected Female", which were sent to Brontë by her publisher George Smith. The scenes describe mostly various travelling mishaps of the "unprotected female" of the title, usually carrying large amounts of luggage, perplexed about which omnibus, train or ship she should take, and comically falling off the wharf, or nearly so. The lady is portrayed as not so much in danger of being actually harassed or assaulted, but rather herself being a nuisance to the conductors or fellow-passengers because of her helplessness and confusion. Comic as these adventures are, they can be interpreted as a symptom of the social change. The women who could not afford private carriages took advantage of increasingly more accessible and safer modes of public communication, and a number of them, perhaps small but significant enough to be noticed by the Punch writer, must have done it without a male guardian. Punch's conservative satire can be read as assuaging the fear inspired by this new mobility of women - its "unprotected female" is portrayed as unable to move in the world at large without male guidance. But one can interpret it also as inadvertently questioning the mode of life in which middle- and upper-class women are simultaneously cosseted and cordoned off from the real world, unable to function in it.

Brontë's writings show how keenly she felt the insufficiency of this ideal of womanhood. In a letter to George Smith informing him that she is still waiting for the parcel with books (and presumably the issues of Punch) she writes: "I wait in all reasonable patience and resignation, looking with docility to that model of active self-helpfulness Punch friendly offers the 'Women of England' in his 'Unprotected Female”" (“To George Smith”, Brontë 1908: 120). And in Villette published a few years later, Lucy Snowe travelling as "an unprotected female" to London for the first time in her life braves her own painful shyness, the superciliousness of the inn servants and the noise of London streets; after the moment of initial dejection she starts to enjoy deeply the experience and the freedom of roaming the streets of London on her own: "I went wandering whither chance might lead, in a still ecstasy of freedom and enjoyment; and I got - I know not how - I got into the heart of city life” (Villette, 113).

By the 1860s the term seems to have become completely a joke, at least in liberal circles; in 1866 the Irish suffragist Frances Power Cobbe wrote in a private letter, referring to the trip to Rome planned by her partner Mary Lloyd "as if I were going to let my wife run about the world like an unprotected female \& leave me behind!” (quoted after Mitchell 2004: 157). 
After Lucy tastes this freedom with all its dangers (the first evening after her arrival in Villette Lucy is followed in the street by two men), she sees how severely it is curtailed in Madame Beck's school. This contrast between the Continental and English approach to freedom granted to women is often discussed in Villette. All-pervasive surveillance is the most important tool of Madame Beck, Lucy's employer, to keep control over the pensionnat and all its inhabitants. She is no exception in Labassecour: spying and surveillance are portrayed in the novel as "instruments of social control in Roman Catholic society, necessary in the absence of the internal self-discipline that characterizes the English Protestant" (Clarke 2011: 977). Madame is quite frank about her methods; while she professes to admire Englishwomen and "their superior intelligence, and more real and reliable probity" (Villette, 138), she claims she is unable to follow the English approach to upbringing:

[S]he seemed to know that keeping girls in distrustful restraint, in blind ignorance and under a surveillance that left them no moment and no corner for retirement, was not the best way to make them grow up honest and modest women; but she averred that ruinous consequences would ensue if any other method were tried with continental children - they were so accustomed to restraint, that relaxation, however guarded, would be misunderstood and fatally presumed on: she was sick, she would declare, of the means she had to use, but use them she must.

(Villette, 138)

In keeping with this, Madame Beck guards her pupils carefully, especially when it comes to their contacts with young men. Although at her annual fête she allows, by the special application of her students' families, the attendance of their brothers, they are confined to a separate room and can look at the girls only from afar; asking them to dance is unthinkable. The pensionnaires are not allowed to take walks in "l'allée défendue", or the garden path that runs parallel to the wall of the neighbouring boys' college. Lucy, as an adult woman, is allowed more freedom, including walks in the forbidden part of the garden; still, her private belongings are searched on several occasions by Madame and her life is submitted to a similar kind of scrutiny as the pupils' are.

Madame Beck's methods prove ineffective at the end of the novel, when despite her watchfulness Ginevra Fanshawe elopes with her lover, with whom, as it turns out, she has been corresponding and making assignations for several months past. Brontë, in a nice touch of irony, makes her the same "jeune Mees" who was apparently trustworthy enough to travel alone to Labassecour on the same packet as Lucy. However, as Lucy and the readers learn in the course of the novel, Ginevra is the daughter of worldly and neglectful parents, and she has spent all her life being moved from one European boarding school to another. Her speech is peppered with French phrases and she herself freely admits she 
does not know whether she is a Protestant or not. In a manner of speaking, she lost her caste as an Englishwoman, and can be treated as an example of the results of a continental education. What is more, by making an English girl the biggest failure of Madame Beck's system Brontë indicates that the vaunted modesty and uprightness of Englishwomen is not their innate feature but a benefit of their education. She makes a similar point more bluntly in The Professor. In that novel the narrator, an English male teacher in a Belgian school, differentiates between what he calls "continental English" and "British English", that is, English girls from expat families, who spent most of their lives on the Continent and those who grew up in England. The former, like Ginevra, "had never known the advantages of settled homes, decorous example, or honest Protestant education; resident a few months now in one Catholic school, now in another, as their parents wandered from land to land" (The Professor, 98). The latter, on the other hand, can be immediately recognized owing to their "grave and modest countenances, a general air of native propriety and decency; by this last circumstance alone I could at a glance distinguish the daughter of Albion and nursling of Protestantism from the foster-child of Rome, the protegee of Jesuistry" (The Professor, 98-99).

While in Villette Brontë limits herself to scattered remarks about the Labassecourian girls lacking pure-mindedness, in The Professor she writes yet without the restraint she learnt as a writer later on:

\begin{abstract}
They were each and all supposed to have been reared in utter unconsciousness of vice. The precautions used to keep them ignorant, if not innocent, were innumerable. How was it, then, that scarcely one of those girls having attained the age of fourteen could look a man in the face with modesty and propriety? An air of bold, impudent flirtation, or a loose, silly leer, was sure to answer the most ordinary glance from a masculine eye. I know nothing of the arcana of the Roman Catholic religion, and I am not a bigot in matters of theology, but I suspect the root of this precocious impurity, so obvious, so general in Popish countries, is to be found in the discipline, if not the doctrines of the Church of Rome. I record what I have seen: these girls belonged to what are called the respectable ranks of society; they had all been carefully brought up, yet was the mass of them mentally depraved.
\end{abstract}

(The Professor, 93-94)

The more specific information about the root of the evil, while not spelled out either in The Professor or in Villette, can be inferred from the remarks made in Villette about the confession and the role it plays in Labassecour, "this land of convents and confessionals" (Villette, 166). The confession, as has been indicated before, was from the Protestant point of view the ultimate abandonment of the exercise of one's own conscience and putting one's trust in "a mediator as helpless and as sinful as himself" (Anonymous 1852: 384); the absurdity of asking God for forgiveness through a fellow sinner was one of the most often used ar- 
guments in Protestant polemic writing, to which Brontë also alludes when writing "[m]an, your equal, weak as you, and not fit to be your judge, may be shut out thence - take [the secrets of your soul] to your Maker" (Villette, 248) (ClarkBeattie 1986: 284). From the viewpoint of Lucy, as a Protestant, the girls, subject to the obligatory monthly ritual, never develop a conscience of their own; their behaving well can be assured only by constant spying on them and imposing penalties when they slip, which is essentially how the mechanism of confession and penance works. The preservation of their innocence, as can be seen from the above quotes from Villette, means mostly, if not exclusively, the protection of their sexual innocence; that is why Madame Beck is so assiduous in keeping her students away from any young men. However, the confessional itself was perceived in the Protestant culture as the place of sexual corruption, either as the place of actual physical seduction (in the tradition hailing from the Gothic novel and kept alive by penny dreadfuls [Paz 1992: 62]), or as the place of moral seduction, as was confirmed by numerous popular publications containing excerpts from the handbooks for confessors by such Roman Catholic authorities as Pierre Dens and Alphonsus Liguori. One such publication, under the concise title Saint Alphonsus Liguori, or Extracts from 'The Moral Theology' of the Above Romish Saint, Who Was Canonized in the Year 1839, with Remarks Thereon by the Rev. R. P. Blakeney, B.A, quotes 72 questions concerning various technical details of transgressions against the sixth and ninth commandment (or, in the Protestant tradition, seventh and tenth) and a large chunk of Liguori's commentary on them. All of the above are quoted only in the original Latin since, as two Evangelical clergymen, John Cumming (known nowadays only as the subject of George Eliot's scathing article) and Thomas Hartnell Horne certify at the beginning of the book, "the Latin not translated in this Volume, especially that on the Confessional is unfit for Protestant eyes or ears, and must therefore be left in its original" (Blakeney 1852: xiii). Obviously, "Protestant eyes or ears" did not include the eyes of educated men who, knowing Latin, could become acquainted with the exposition of these depravities. "If the very mention of these sins be enough to pollute the mind, according to the statement of Liguori himself, what must be the

4 The Protestant Electoral Union learnt much to its cost that this boundary should not be crossed when in 1867 it published a similar book, The confessional unmasked, containing the translations of the racy passages. The pamphlet was confiscated on the grounds of obscenity, despite the protestations of its publishers about their honest intentions to "[expose]... the errors of the church of Rome" (Regina 1868). The ruling made during the appeal trial by Justice Alexander Cockburn that in obscenity trials it is the predicted effect of the work on the audience, and not the avowed intention of the author that should be considered, is still referred to in legal writings on obscenity laws as "the Hicklin test", after the name of the defendant. The Hicklin case and its repercussions in Victorian culture were discussed by a number of authors, among them Arnstein 1982: 89-90, 238 n. 28, Kendrick 1987: 120124, McDonald 2008, and most recently by Janes 2013. 
result when they become the subject of conversation in the confessional, the dark deeds of which no mortal eye beholds" (Blakeney 1852: 165), exclaims the editor of the book; from his point of view the act of confession, nominally cleansing one's soul, is actually the act of pollution.

While Brontë alludes only in passing to the apparently endemic impurity of Catholic women's minds, the confessional still plays an important role in Villette, not so much as the place of corruption, as in the tradition described above, but as the instrument of control of priests over their penitents, an equally vivid trope in Protestant writings, dating back to Foxe and his cunning abbots, who used the confession as a means to send their monks on suicide missions. The confessional in Villette, if not as frightening as many of contemporary English writers claimed, is the place where priests exercise control over their penitents. It is referred to as such for the first time when Lucy describes her reaction to lecture pieuse, the evening ritual of reading saints' lives to the boarders. The reading includes excerpts from the story of St. Elizabeth of Hungary; what is considered by Catholics to be a shining example of Christian humility and obedience is perceived by the only Protestant member of the audience as a deeply offensive story about a noble lady whose life was ruined by her confessor:

\begin{abstract}
The ears burned on each side of my head as I listened, perforce, to tales of moral martyrdom inflicted by Rome; the dread boasts of confessors, who had wickedly abused their office, trampling to deep degradation high-born ladies, making of countesses and princesses the most tormented slaves under the sun. Stories like that of Conrad and Elizabeth of Hungary, recurred again and again, with all its dreadful viciousness, sickening tyranny and black impiety: tales that were nightmares of oppression, privation, and agony.
\end{abstract}

(Villette, 183)

Brontë's interpretation of the story of St. Elizabeth of Hungary is influenced by Charles Kingsley's The Saint's Tragedy (1848), a book she read and admired (“To Mrs Gaskell”, Brontë 1908: 228). In Kingsley's retelling of this story Elizabeth is a kind-hearted, gentle, loving woman, separated from her husband and children by her confessor Conrad of Marburg, who ruins her life by making her believe that only extreme asceticism, thwarting all natural affections and impulses, is the way to salvation. Similarly, the Church attempts to control Paul's affections through "that mystic lattice... the sliding panel of the confessional" (Villette, 482). It is through the confession that Père Silas learns about Paul Emanuel's developing feelings for Lucy and attempts to control them: "The penitent had been with his director; permitted to withhold nothing; suffered to keep no corner of his heart sacred to God and to himself; the whole narrative of our late interview had been drawn from him" (Villette, 487). When Père Silas's efforts to convert Lucy fail, he sets about to send M. Paul on the 
fateful journey to Guadaloupe, achieving through this the dual purpose of supplying Madame Walravens, his generous donor, with "the best and faithfullest steward" (Villette, 534) for her estate and cutting off Emanuel's entanglement with a heretic. Thus, through the medium of confession, the Church exercises full control even over the most intimate details of the lives of its members: $\mathrm{M}$. Paul has to acknowledge his love for Lucy to his confessor even before he declares his love to Lucy herself.

All that being said, the attitude towards confession in Villette is more complicated than one could assume on the basis of the above examples. In one episode (modelled on Brontë's own experience in Brussels) Lucy, left alone at the pensionnat for the long summer vacation, overcome by depression and the unexpressed love for Dr. John, goes one evening to confession and finds solace there in "the mere pouring out of some portion of long accumulating, long pentup pain into a vessel whence it could not be again diffused" (Villette, 231). As LaMonaca (2008: 87-88) points out, the confession is for Lucy not just a nineteenth-century equivalent of a psychotherapist's couch: its importance relies on the fact that its very existence is the sign that the Church acknowledges and in some way validates the presence of transgressive or sinful passions in women as well as men. In a culture where the images of femininity range from the voluptuous courtesan to the insipid wife and mother, epitomized by the paintings Lucy sees at the museum, the institution of the confession proves that even respectable women may be subject to temptations.

Despite Père Silas's encouragement that "our faith alone could heal and help you" (Villette, 231), after this emotional crisis Lucy deals with her passions according to her "self-reliant, invulnerable creed" (Villette, 490). When Dr Bretton, preoccupied with his growing feelings for Paulina, forgets about his promise to write to Lucy to cheer her up in the solitude of the boarding-school, she gathers all the five letters she received from him and buries them under the roots of the old pear tree in the school garden. This act of symbolically disposing of one's own passions is explicitly compared to the confession: "[t]he impulse under which I acted, the mood controlling me, were similar to the impulse and the mood which had induced me to visit the confessional" (Villette, 367). While in the confessional Lucy is allowed to pour her emotions out, in the act of burying Dr John's letters she suppresses them, or entombs them alive with her own hands. An important sub-plot of Villette concentrates around the spectral nun, who was allegedly buried alive in what was later going to become the school garden by "the monkish conclave of the drear middle ages ... for some sin against her vow" (Villette, 172); Lucy re-enacts this story, playing both the part of the executioner and the victim, as she punishes herself for her sin and later on is haunted by the dreams of her love becoming the living dead: "[s]ometimes I thought the tomb unquiet, and dreamed strangely of disturbed 
earth, and of hair, still golden and living, obtruded through coffin-chinks" (Villette, 435). Madame Beck says approvingly that, peculiar as the English character is, "[m]ais au moins il n'est pas besoin de les surveiller" (Villette, 365). There is no need to monitor Lucy's behaviour because, a good little Protestant girl that she is, she is going to strangle her desires out of her own accord, motivated by Reason (often depicted in Villette allegorically as an old hag), "the voice of Protestant independence and self-restraint” (Clark-Beattie 1986: 845).

Lucy's whole upbringing taught her to punish herself for the desires she harbours, while the Catholic conscience is externalized, with penalties imposed by those in authority. The Catholic attitude to desires is embodied in the approach of Madame Beck towards her eldest daughter, appropriately named Désirée (LaMonaca 2008: 87-88). She is "a vicious child", constantly plaguing the servants; however, her mother's response to the reports about Désirée's antics is the serene observation "Désirée a besoin d'une surveillance toute particulière". Madame Beck apparently has given up all idea of moral upbringing: "[n]ever once, I believe, did she tell her faithfully of her faults, explain the evil of such habits, and show the results which must thence ensue. Surveillance must work the whole cure" (Villette, 159). While the Protestant Lucy has to control herself, Désirée can allow her desires to run rampant, safe in the knowledge that the responsibility for curtailing them lies with somebody else.

It is interesting to observe that, while Dr Bretton appears for the first time at the pensionnat to treat the broken arm of Fifine, Désirée's sister, it is during Désirée's simulated illness, which follows Fifine’s recovery, that Lucy recognizes him as Graham Bretton, her godmother's son with whom, as early chapters suggest, Lucy was in love as a teenager. Although Lucy Snowe is a notoriously reticent narrator, one may assume it was during Dr Bretton's visits to Désirée when Lucy's love for him was reawakened. Later Désirée disappears from the pages of the novel and reappears, significantly enough, in connection with another important man in Lucy's life - in the oneiric scene when Lucy, drugged by Madame Beck, who tries to keep her away from M. Paul, goes to look for him during the evening fête in the park. It is one of these rare moments when Lucy's inhibitions disappear, perhaps partly thanks to the unintended consequences of Madame Beck's drugs and she actively pursues the man she loves and whom she suspects (unjustly, as it turns out) of being unfaithful to her. And it is actually Désirée whom Lucy recognizes first in the group of family and friends of $\mathrm{M}$. Emanuel in the shadows of the park. Her "perverse movements ... of a character fearfully familiar” (Villette, 531) allow Lucy to recognize Désirée - and her own desires.

However, this recognition does not mean that Lucy is allowed to express her desire. In the end, the codes of conduct for unmarried young women in England and Labassecour do not differ that much: they both require chastity, not only in deeds but also in thoughts and words. In keeping with this, both Lucy and Pau- 
lina carefully compose their letters to Dr Bretton lest they appear too cordial. Even Paulina, who, unlike Lucy, has received an open declaration of love from John, rewrites her answer three times until it resembles "a morsel of ice flavoured with ever so slight a zest of fruit or sugar" (Villette, 448); this attitude is praised by Lucy as "that gentle hoar-frost of yours, surrounding so much pure, fine flame" (Villette, 449). While the decorous behaviour of Madame Beck's students is ensured by their being disciplined and punished through the joined apparatuses of school and church, the Protestant mode of upbringing, Brontë suggest, results in something far more precious than appropriate deportment: self-control and self-restraint, the two virtues invariably praised by the authors of Victorian conduct books. ${ }^{5}$

Throughout the novel Lucy exercises this self-control, even when, as is the case with her thwarted love for Dr John, it results in a psychosomatic illness. Through this, she proves she deserves her freedom, costly as it may be. The assumption in the whole discourse about the liberty of women was that they could not be granted as much freedom as men because of their physical and mental weakness: they could be assaulted sexually or they could easily give in to temptations. Men were as prone to these temptations, but in case of women they bore far more grievous consequences. This double standard is illustrated by Lucy's visit to the museum mentioned at the beginning of this article: while $\mathrm{M}$. Paul scolds her for looking at what he considers an indecent painting, he himself looks at it "quite at his ease, and for a very long while" (Villette, 272).

The encounter at the museum is also illustrative of how taxing Lucy's independence is. Despite her protestations, it is apparent that Lucy gives in to M. Paul's bullying (on this as on other occasions) with a kind of masochistic pleasure; his ordering her around and telling her where to look takes off from her shoulders the responsibility to choose for herself the paintings at which a "demoiselle" can glance without endangering propriety. While everyone around her, including Lucy herself, perceives her as a plain old maid, Paul Emanuel repeatedly calls her a "coquette", "flirt" and tells her "[y]ou want so much checking, regulating and keeping down" (Villette, 436). And this is indeed what Lucy "wants" in a different sense of the word: she does yearn for somebody who could relieve her from the burden of checking, regulating and keeping herself down. With M. Paul as the self-appointed guardian of her morality, she can let her passions run rampant, safe in the knowledge that he would be only too happy to intervene whenever she crossed a boundary.

Cf. e.g. Sarah Stickney Ellis' exhortation to fiancées: "there is implanted in the nature of woman, a shrinking delicacy, which ought ever to prompt her to keep back some of her affection for the time when she becomes a wife. No woman ever gained, but many, very many, have been losers, by displaying all at first” (Ellis 1842: 237). 
However, it has to be noted that the control of M. Paul has its limits. Much of their relationship has masochistic undertones (as in many of Brontë's novels), with Lucy deliberately provoking M. Paul to anger, as in chapter 29 when she withholds from him a long-prepared and expected gift. One also senses that it is Lucy's backtalk that makes her attractive to Paul; as she herself observes, "nothing drove him so nearly frantic as the tremor of an apprehensive and distrustful spirit; nothing soothed him like confidence tempered with gentleness" (Villette, 273). But issues of religion seem to be exempt from this game of give-and-take, as can be observed in the passage where M. Paul plants a Catholic tract in Lucy's desk with the intention of converting her. The scene begins similarly to many other quarrels that punctuate their relationship: Paul asks Lucy whether she was touched by the tract; she nonchalantly produces her handkerchief to show that it is completely dry. He loses his temper and starts to harangue her, while she coolly eats chocolates she has received from him, sharing them with Madame Beck's pet spaniel. But when he asks her seriously about her real views on religion, they have an earnest discussion, different from their usual banter. In the end Paul lets Lucy stay true to her faith, writing "My little English Puritan, I love Protestantism in you" (Villette, 566). Lucy's staunch adherence to Protestantism also shows that ultimately she deserves her freedom: her adherence to her religion is not assured, as in the case of her students, by the ideological apparatus of school and church, with the obligatory prayers, confessions and lecture pieuse, but by her own conviction strengthened by Bible reading.

Still, proud as Lucy is of her freedom as a Protestant Englishwoman, it is a mixed blessing, taking into account how restricted it is for somebody in her social position; when Madame Beck in lieu of a gift promises Lucy to "leave [her] alone with [her] liberty". Lucy reciprocates by "voluntarily respecting her rules" (Villette, 370). This small episode encapsulates the problematic nature of Lucy's freedom; to borrow the terminology of political philosophy, she may be granted a modicum of negative freedom (from interference in her private affairs) but only because she can be trusted to behave exactly in the way expected of her by society and culture. Her self-determination and self-mastery turn out thus to be drastically limited, with Lucy herself setting the limits. While Lucy struggles throughout the novel to protect her freedom from the prying eyes of Madame Beck, she realizes that her freedom is the recognition of necessity.

Villette draws on a tradition of Protestant pride in its self-discipline, independent conscience, and freedom that was supported by centuries of rhetoric. The novel reproduces many of the ideas advanced by Protestant advocates regarding the superiority of Protestantism to Catholicism by emphasizing the way in which English girls and women could be trusted to do the right thing while Catholic girls and women required constant surveillance and external control. And yet the novel complicates this binary by showing that for women, Protes- 
tant "freedom" required a level of self-suppression in order to conform to society's expectations that could lead to psychosomatic illness, while Catholicism acknowledged women's desires and provided in the confessional what Lucy Snowe terms a "pouring out" of pain. Thus the novel subtly interrogates Protestant assumptions of superiority to Catholicism by showing that both traditions were repressive for women, because the external surveillance of the Catholic system of education was equalled by the demand for self-surveillance of the Protestant system.

\section{REFERENCES}

Anonymous. 1861. A few words on tours and tourism. Fraser's Magazine 63 (March). 340-355. Anonymous. 1852. Review of Scriptural revision of the liturgy, a remedy for Anglican assumption and papal aggression. A letter to the right honourable John Russell, M.P. by a member of the Middle Temple. The North British Review 17 (August). 369-421.

Arnold, Matthew. 1993 [1869]. Culture and anarchy: An essay in political and social criticism. In Stefan Collini (ed.), Arnold's Culture and anarchy and other writings. 53-212. Cambridge: Cambridge University Press.

Arnstein, Walter L. 1982. Protestant versus Catholic in mid-Victorian England: Mr Newdegate and the nuns. Columbia and London: University of Missouri Press.

Blakeney, R.P. 1852. Saint Alphonsus Liguori, or Extracts from 'The moral theology'. London: The Reformation Society.

Boswell, James. 1998. Life of Johnson. Oxford: Oxford University Press.

Brontë, Charlotte. 1908. To George Smith. 16 March 1850. In Clement King Shorter (ed.), The Brontës: Life and letters. Vol. 2, 119-120. London: Hodder \& Stoughton, repr. 2013. Cambridge: Cambridge University Press.

Brontë, Charlotte. 1908. To Mrs Gaskell. 6 August 1851. In Clement King Shorter (ed.). The Brontës: Life and letters. Vol. 2, 226-228. London: Hodder \& Stoughton, repr. 2013. Cambridge: Cambridge University Press.

Brontë, Charlotte. 1948. The Professor. West Drayton: Penguin.

Brontë, Charlotte. 2006. Villette (edited by Kate Lawson). Peterborough, ON: Broadview Press.

Burstein, Miriam Elizabeth. 2005. Reviving the Reformation: Victorian women writers and the Protestant historical novel. Women's Writing 12(1). 73-84.

Clark-Beattie, Rosemary. 1986. Fables of rebellion: Anti-Catholicism and the structure of Villette. English Literary History 53(3). 821-847.

Clarke, Micael M. 2011. Charlotte Brontë's Villette, mid-Victorian anti-Catholicism, and the turn to secularism. English Literary History 78(4). 967-989.

Colley, Linda. 1992. Britons: Forging the nation 1707-1837. New Haven and London: Yale University Press.

Ellis, Sarah Stickney. 1842. The daughters of England. New York: D. Appleton.

Engelhardt, Carol Marie. 2000. Victorian masculinity and the Virgin Mary. In Andrew Bradstock et al. (eds.), Maculinity and spirituality in Victorian culture, 44-57. Houndsmills: Palgrave Macmillan. 
Fatovic, Clement. 2005. The anti-Catholic roots of liberal and republican conceptions of freedom in English political thought. Journal of the History of Ideas 66(1). 37-58.

Foxe, John. 1570. The unabridged Acts and Monuments online. Sheffield: HRI Online Publications, 2011. http://www.johnfoxe.org (accessed 31 December 2013).

Gilbert, Sandra M. \& Susan Gubar. 1979. Madwoman in the attic. New Haven: Yale University Press.

Griffin, Susan M. 2004. Anti-Catholicism and nineteenth-century fiction. Cambridge: Cambridge University Press.

Janes, Dominic. 2013. The confessional unmasked: Religious merchandise and obscenity in Victorian England. Victorian Literature and Culture 41(4). 677-690.

Kendrick, Walter. 1987. The secret museum: Pornography in modern culture. Berkeley \& Los Angeles: University of California Press.

Klaus, Robert J. 1987. The Pope, the Protestants and the Irish. New York: Garland.

LaMonaca, Maria. 2008. Masked atheism: Catholicism and the secular Victorian home. Columbus: The Ohio State University Press.

McDonald, Peter. 2008. Old phrases and great obscenities. The strange afterlife of two Victorian anxieties. Journal of Victorian Culture 13(2). 294-302.

Mitchell, Sally. 2004. Frances Power Cobbe: Victorian feminist, journalist, reformer. Charlotesville: University of Virginia Press.

Moran, Maureen. 2007. Catholic sensationalism and Victorian literature. Liverpool: Liverpool University Press.

O’Malley, Patrick R. 2006. Catholicism, sexual deviance and Victorian Gothic culture. Cambridge: Cambridge University Press.

Parry, J.P. 2006. Liberalism and liberty. In Peter Mandler (ed.). Liberty and authority in Victorian England, 71-100. Oxford: Oxford University Press.

Paz, D.G. 1992. Popular anti-Catholicism in mid-Victorian England. Stanford: University Press.

Regina v. Hicklin. 1868. L.R. 3 Q.B. 360. Court of the Queen’s Bench. http://en.wikisource.org/ wiki/Regina_v._Hicklin (accessed 2 November 2012).

Schiefelbein, Michael E. 2001. The lure of Babylon. Seven Protestant novelists and Britain's Catholic revival. Macon: Mercer University Press.

Tumbleson, Raymond. 1998. English Protestant imagination: Nationalism, religion and literature, 1660-1745. Cambridge: Cambridge University Press

Wallis, Frank H. 1993. Popular Anti-Catholicism in mid-Victorian Britain. Lampeter: E. Mellen Press.

Wheeler, Michael. 2006. The old enemies. Catholic and Protestant in nineteenth-century English culture. Cambridge: Cambridge University Press.

Wolffe, John. 1991. The Protestant crusade in Great Britain 1829-1860. Oxford: Clarendon Press. 